\title{
Corpo caligráfico, voz: as escritas em performance de Manoel Ricardo de Lima e Sérgio Medeiros
}

\author{
Calligraphic Body, Voice: The Performance Writings \\ of Manoel Ricardo de Lima and Sérgio Medeiros \\ Cuerpo caligráfico, voz: los escritos en performance \\ de Manoel Ricardo de Lima y Sérgio Medeiros
}

Annita Costa Malufe*

\section{Resumo}

O artigo busca apresentar e comentar obras de dois autores contemporâneos e brasileiros, os poetas e escritores Manoel Ricardo de Lima e Sérgio Medeiros, buscando, através de suas escritas, definir aquilo que poderia ser considerado um traço "performático", marcante em algumas tendências da literatura de hoje. A principal característica dessas escritas performáticas seria a presença do corpo do próprio escrito e a mescla e indistinção de gêneros artísticos. Para tanto, parte-se do conceito de "performance" de Paul Zumthor, para estendê-lo à leitura crítica de alguns textos dos autores Lima e Medeiros, em diálogo com outros artistas e pensadores do teatro, como Antonin Artaud, Samuel Beckett e Hans-Thies Lehmann.

Palavras-chave: performance, corpo, Manoel Ricardo de Lima, Sérgio Medeiros.

\begin{abstract}
This article deals with the works of two contemporary Brazilian writers, Manoel Ricardo de Lima and Sérgio Medeiros, seeking to define, through the analysis of their work, what today may be called a "performatic" trace in contemporary literature. The main characteristics of these performatic writings would include the presence of the body in writing, together with the intermingling and indistinction of artistic genres. Paul Zumthor's concept of "performance" followed by readings of Artaud, Beckett and Hans-Thies Lehman are used to think through Lima and Medeiros' work in light of a "performatic literature."
\end{abstract}

Keywords: performance, body, Manoel Ricardo de Lima, Sérgio Medeiros.

\section{Resumen}

El artículo busca presentar y comentar las obras de dos autores contemporáneos y brasileños, los poetas y escritores Manoel Ricardo de Lima y Sérgio Medeiros, buscando, a través de sus escrituras, definir lo que podría considerarse una característica "performativa", sobresaliente en algunas tendencias de la literatura de nuestros días. La principal característica de esas escrituras performativas sería la presencia del cuerpo del escrito y la mezcla e indistinción de géneros artísticos. Para esto, partimos del concepto de "performance", de Paul Zumthor, para extenderlo a la lectura crítica de algunos textos de los autores Lima y Medeiros, en diálogo con otros artistas y pensadores de teatro, como Antonin Artaud, Samuel Beckett y Hans-Thies Lehmann.

Palabras clave: performance, cuerpo, Manoel Ricardo de Lima, Sérgio Medeiros.

\section{O corpo da voz}

Na tentativa de aproximação a determinados textos literários contemporâneos, um termo parece impor-se com força: performance. E, ao seu redor, diversos fatos contextuais, manifestações artísticas históricas, bem como diferentes teorizações, advindas de diversos lugares e mesmo campos disciplinares (o teatro, a dança, as artes visuais, a música, a

\footnotetext{
* Pontifícia Universidade Católica de São Paulo (PUC-SP), São Paulo, SP, Brasil. (Dorcid.org/0000-0002-6843-197X. E-mail: annitacostamalufe@gmail.com
} 
antropologia, a história da arte), vêm juntar-se. ${ }^{1}$ Um campo grande se abre na exploração de um traço, que este artigo definirá por performático, característico de certas escritas de hoje. ${ }^{2}$ Escritas que, em geral, não se fixam em um gênero literário específico, bem como não se localizam em apenas uma modalidade de discurso, tampouco linguagem. Escritas que, ao mesmo tempo, colocam em pauta diversas naturezas de presença: a de seu próprio corpo, enquanto materialidade, a do corpo do leitor-receptor e, ainda, a do tempo presente, o instante em que se dá seu próprio acontecimento enquanto obra.

Dizer que determinados traços de uma obra poderiam se reunir em torno do adjetivo "performático" exige ao menos uma breve explicação do que aqui compreenderemos pelo termo "performance". Como base principal e ponto de partida, tenho em vista algo que, em literatura e em poesia, foi bastante trabalhado pelo medievalista Paul Zumthor, ao explorar a prática das poéticas orais nas canções medievais. Não tanto por sua extensa e consistente pesquisa dessa espécie de origem do que virá a ser a nossa poesia escrita, mas muito por aquilo que foi capaz de teorizar a respeito da própria natureza dessas manifestações. Zumthor é um dos raros estudiosos a conceituar a performance, ou seja, a fazer do termo de fato um conceito e não somente a descrição de um fato empírico. Em Zumthor, embora a audição pública de um poema possa ser chamada de performance, o termo não se restringe ao gênero de uma manifestação artística, mas vai além, dizendo respeito à natureza de um dado acontecimento dito poético. ${ }^{3}$ Atrelando o literário à experiência de escuta e vivência do texto, ele desloca o eixo dos estudos por demais centrados na estrutura textual, propondo a ênfase na relação intrínseca entre Performance, recepção, leitura (título de uma de suas obras), enquanto três termos de uma mesma experiência, poética ou artística, da qual o texto literário não existiria jamais separadamente.

Nessa experiência, encontra-se sobretudo o fato de que o corpo está implicado desde o início: a experiência poética/artística se define justamente por uma forte implicação corporal, por uma mistura de corpos que acontece no instante da leitura/audição/recepção da obra: “A performance é a ação complexa pela qual uma mensagem poética é simultaneamente, aqui e agora, transmitida e percebida. Locutor, destinatários e circunstâncias [...] se encontram concretamente confrontados" (Zumthor, 1997, p. 33). Instante em que os corpos do leitor, auditor, espectador e aquele do próprio texto, do som, dos materiais envolvidos em todo contexto, encontram-se e, em conexão, criam esse espaço-tempo da performance. ${ }^{4}$ Trata-se de um ato teatral, dirá Zumthor (2005, p. 69), "em que se integram todos os elementos visuais, auditivos e táteis que constituem a presença de um corpo e as circunstâncias nas quais ele existe".

Entre esses elementos físicos e sensíveis que se integram na performance, a voz ocuparia um lugar especial para Zumthor. A voz é corpo presente, material: "A voz é presença" (Zumthor, 2005, p. 93), diz. E muito da singularidade de seu conceito de performance vem desta centralidade da voz; daí decorre a constatação de que: "A performance não pode ser outra coisa senão presente" (Zumthor, 2005, p. 93). A voz, fonte da poesia em seus primórdios e desejo latente nas poéticas de hoje, marcaria a experiência poética enquanto busca de fazer corpo, desejo e "nostalgia da voz viva" (Zumthor, 2005, p. 69), em sua materialidade de som, respiração, sopro, evidência física.

\footnotetext{
${ }^{1}$ Como bem observa Edélcio Mostaço (2009), no artigo "Fazendo cena, a performatividade", os estudos performáticos nasceram no ambiente teatral, mas o extrapolaram de tal modo que, hoje, numa espécie de inversão, o teatro é tomado como uma parte desses estudos.

2 Cito como exemplo a proximidade com o conceito de escrita performativa, apontado por Ana Bernstein, enquanto um desdobramento de relações entre a teoria de Austin dos atos de fala e os estudos da performance: "Della Pollock define a escrita performativa como uma escrita que opera 'no intervalo entre escrita e performance'. A escrita performativa visa a fazer o texto atuar. Se a característica da ação é transformar o mundo de alguma forma, a escrita performativa deve ser capaz de intervir e transformar a realidade" (Bernstein, 2004, p. 66). Entretanto, sobretudo no que concerne à questão do modo de subjetivação aí operado, há diferenças com o que proponho neste artigo, de modo que não irei me deter no presente texto nas proximidades e distâncias com tal noção.

${ }^{3}$ Ao mesmo tempo, vale salientar que, nos escritos de Zumthor, a performance nada tem a ver com desempenho (de um papel social, por exemplo), como em algumas teorias da antropologia ou da psicologia social.

${ }^{4}$ Assim, é esse instante que define o espaço-tempo da performance; não há obra sem esse instante ou, ainda, é "obra" aquilo que se fará nesse instante de seu acontecimento. Sendo toda obra, para Zumthor, dependente de sua performance e, portanto, atrelada ao que se compreende por recepção, mas que, aqui, inclui também todos os elementos contextuais.
} 
É nesse sentido que, dentre as poéticas brasileiras significativas de hoje, somos remetidos àquela de Manoel Ricardo de Lima, ${ }^{5}$ na qual encontramos um caso singular desse trabalho com o fluxo da voz viva, presentificando o corpo da escrita e convocando o corpo do leitor. Em Manoel Ricardo de Lima, o caráter performático muitas vezes está na presença concreta de vozes, frequentemente marcadas pela urgência de dizer ou gritar, de se tornar corpo que salte da página para o corpo do leitor. Sendo, assim, a presença da voz em seu movimento e, ao mesmo tempo, a presença do corpo do livro que marcam o espaço de performance aberto pela experiência dessa obra.

Tal trabalho se dá em praticamente todos seus livros, mas é em Onde você está, que o caráter performático salta-nos aos olhos e aos ouvidos, de forma emblemática: desde o projeto gráfico, a constituição das manchas do texto, o título que nos convoca com um "você" impresso em vermelho e as vozes que se fazem presentes de modo eloquente e incisivo, tudo nesta poética nos remete ao fluxo vocal e seu ritmo:

\section{onde mora jonah hex}

abro a boca na sua frente. enfie o nariz dentro dela até onde conseguir. sinta o cheiro das minhas gengivas banguelas, é o mesmo do intestino grosso, guarda de muco, consistência do bolo de merda, da morte e da fumaça acre do cano das pistolas no peito, no olho. não sei se entende, entende? às vezes até acho que sim, muito pouco, me iludo que sim, mas sei que não consegue. isto é uma pena, meu desejo é ir embora, with the man, ser poeta no oeste, livre e no século passado, liberdade para traçar meu endereço, numa cidade pequena, cheia de buracos de bala e porres de uísque, lugar em que todo homem tem um preço, uma cabeça a prêmio. paulo leminski nunca quis nada, também podia ter outro nome, lapaxipapakiki ou bagundalagagun. é como se estivesse pensando em mim, em você, boca aberta e suspensa, a pele solta. o mesmo homem de cidade nenhuma, moído, um dia homero, sopa rala, noutro navio sem rota, senhorita chuva (Lima, 2016, s.p.).

Esse personagem, Jonah Hex, é um dos que são convocados nos sete textos (poemas-emprosa ou prosas poéticas) que compõem o livro. Cada um dos blocos compactos de texto, manchas quadradas ou retangulares como esse acima, inicia-se com o título: Onde mora..., seguido de nomes próprios que remetem a nomes de super-heróis de quadrinhos, em suas identidades secretas. Neste caso, um pistoleiro, anti-herói de quadrinhos western, e também personagem de minissérie, que possui a face deformada. "Abro a boca na sua frente", ele nos diz e, em seguida, comanda: "enfie o nariz dentro dela até onde conseguir." Um comando direto e incômodo, um convite para que adentremos suas entranhas, seu mal cheiro e precariedade, fedor de gengivas banguelas e fezes. Um misto de asco e violência: a imagem do intestino ecoando naquela do cano da pistola, postas em uma mesma frase, mesmo fluxo, as imagens se entrelaçando e se jogando sobre aquele que lê: "sinta o cheiro das minhas gengivas banguelas, é o mesmo do intestino grosso, guarda de muco, consistência do bolo de merda, da morte e da fumaça acre do cano das pistolas no peito, no olho."

A escolha dessas imagens, extremamente sensoriais e corpóreas, fala do tipo de lugar construído por essa poética: lugar de mistura de corpos, em que escrita e carne se entremeiam. A palavra que é voz é também corpo, pois é garganta, corda vocal, língua, e percorre as mesmas paredes e mucosas pelas quais percorrem os alimentos, a água, a saliva. É por isso que essa poética nos lembra que a voz é experiência do corpo, ainda que estranhamente a tradição escrita muitas vezes tenda a se esquecer disso. Cabe à palavra da poesia tornar sensível, como diz Zumthor, da tatilidade das palavras, o contato real que elas implicam: "Toda palavra poética aspira a dizer-se, a ser ouvida, a passar por essas vias corporais que são as mesmas pelas quais

\footnotetext{
${ }^{5}$ Poeta nascido em 1970 em Parnaíba (Piauí) e desde 2010 residindo no Rio de Janeiro, Manoel Ricardo de Lima é doutor pela Universidade Federal de Santa Catarina (UFSC) e professor da Escola de Letras e no Programa de Pós-Graduação em Memória Social da Universidade Federal do Estado do Rio de Janeiro (Unirio). Juntamente com seu trabalho de escritor, no qual se destacam os livros As mãos / The hands (2003); Quando todos os acidentes acontecem (2009); Jogo de varetas (2012) e Geografia aérea (2014), desenvolve um intenso trabalho crítico e reflexivo acerca da literatura, encontrado em seus diversos ensaios publicados, como por exemplo: Fazer, lugar: a poesia de Ruy Belo (2011) e A forma-formante: ensaios com Joaquim Cardoso (2014).
} 
se absorvem [...] a alimentação, a bebida: como meu pão e digo meu poema, e você escuta ruídos da natureza. E essas palavras entre nós são táteis"' (Zumthor, 2005, p. 69).

Como neste poema, há em cada texto do livro de Lima uma voz que se coloca e que se dirige a um interlocutor não determinado: "não sei se entende, entende?". É uma voz que se coloca presente, diante de nós, na leitura, e nos interpela. As expressões interrogativas que se dirigem a alguém podem ser insistentes, ritmando o texto, como o "você consegue ouvir", em:

\section{onde mora bruce wayne}

você pode até dar um tiro na cabeça a qualquer momento, um poema-suicídio. bum, pra dentro. este mesmo, ali, ou outro. um que não tenha sentido nem nada. não vale a pena nem a raiva nem estrebuchar nem nada. agora escute iessiênin acordado no meio da noite. ele sufoca. ele morre. ele é rápido demais. você consegue ouvir? leningrado e marienhof, zinaida e isadora são nomes esgotados. como é também iessiênin. você consegue ouvir? e estamos todos muito cansados, e estamos todos muito cansados disso tudo. nenhum deles move a quantidade desta hora. nem eu nem você. mas um ruído pode me contar que não demora o lembrete do quarto claro e aberto de iessiênin. você consegue ouvir? está rasurado: uma dançarina americana é muito pouco. andar despenteado é quase nada. amar um campo ou um corpo é extenso, mas é como amar capim, mas é como quem tenta dizer alguma coisa com ternura. parece que a vida ou morrer, vá saber (Lima, 2013/2016, s/n).

Além da intensa presença dessas interpelações diretas, há um ritmo que encarna aquele da vocalidade, que é criado por essas expressões orais que são postas em encadeamento contínuo, sem a presença de maiúsculas em seu início; ou seja, ainda que haja os pontos finais marcando as pausas entre elas, a ausência de caixas altas contribui para suavizar essas quebras e fazer eclodir o escoamento entre as frases. Há uma ênfase no encadeamento, criando esse fluxo contínuo vocal, que ressoa em nós, com sua palpabilidade de voz, com seu fluxo, seu ritmo, suas imagens, seu corpo. Lembramo-nos aqui da afirmação de Zumthor de que a poesia é mais voz do que palavra: "a voz ultrapassa a palavra" (Zumthor, 1997, p. 13), a voz é ela mesma um corpo concreto. É o que ocorre em muitos poemas de Manoel Ricardo de Lima: sentimos saltar o corpo próprio da voz, nesse fluxo vocal que se autonomiza na leitura. Há aqui algo de uma experiência próxima àquela de leitura dos textos em prosa de Samuel Beckett, especialmente aqueles depois de $O$ inominável, em que uma voz se autonomiza dos personagens e se torna ela mesma, em sua materialidade de voz, a personagem principal do romance. Como diz essa voz em Beckett, "não se deve esquecer, algumas vezes esqueço, que tudo é uma questão de voz":

Não se deve esquecer, às vezes esqueço, que tudo é uma questão de voz. O que se passa são palavras. Digo o que me dizem para dizer, na esperança de que um dia deixarão de falar comigo. Apenas, digo-o mal, não tendo orelha, nem cabeça, nem memória. Agora escuto-me dizer que é a voz de Worm que começa, transmito a notícia, pelo que ela vale. Será que eles creem que sou eu que falo? Isso é deles também. Para me fazer crer que tenho um eu para mim e que posso falar dele para mim, assim como eles dos seus (Beckett, 1953, p. 98 , tradução nossa).

No fluxo vocal, elementos os mais díspares, das naturezas as mais distantes, são postos em correnteza. Como diz Gilles Deleuze, sobre os textos de Samuel Beckett, "as vozes são as ondas ou os fluxos que pilotam e distribuem os corpúsculos linguísticos" (Deleuze, 1992, p. 66). O texto é um rio que carrega esses pedaços de imagens, e nossas sensações e memórias com eles. Vamos constituindo assim um tempo-espaço comum com os corpúsculos do texto. E assim, ao ler, somos tomados em um ritmo vocal, no qual nosso corpo faz (novo) corpo com aquele das palavras-vozes.

Assim, ocorre uma partilha de tempo entre texto e leitor: um mesmo fluxo de energia percorre e conecta corpos - letra, sons, músculos, pele, cordas vocais, vibrações internas, fibras, imagens, memórias, lugares, nomes. E aqui podemos nos lembrar da ideia de um "tempo real" da performance, esse do qual partilham todos seus elementos constituintes. Tal tempo é enfatizado tanto por Zumthor, que falará em um tempo corporalizado - "um tempo vivido no corpo: aquilo que denomino um tempo real" (Zumthor, 2005, p. 83) -, quanto por Hans-Thies Lehmann, ao se referir ao traço performático presente nas propostas do teatro (por ele 
denominado) pós-dramático. Para Lehmann, há na performance a criação de um tempo-espaço em que todos, público, atores, texto, espaço, luzes, participam. Daí ela implicar: "uma radical afirmação do tempo real como situação vivenciada em comum" (Lehmann, 2007, p. 304). É dessa vivência temporal comum que emerge o caráter ritual e imersivo dessas propostas, de que nos fala Lehmann, mas que podemos trazer para a experiência dessas escritas performáticas, como a de Beckett, mas também a de Manoel Ricardo de Lima.

Neste ponto, ao apontar o traço de imersão e de ritual dessas escritas, cabe lembrar a prerrogativa de que, aqui, a partir de Zumthor, considera-se que qualquer leitura independentemente de se realizada em silêncio ou na presença de um performer, autor ou ator que a executa em público - é uma performance. De modo que há que se estender a noção do ritual, quando se trata de pensar a natureza dessas escritas performáticas. A leitura literária constrói um espaço de performance e lhe dá permanência, e esse se arma no instante da leitura, independentemente de seu suporte. Espaço-tempo de partilha entre corpos, o do texto e o do leitor. Algo do que já encontramos, mas em outros termos, na concepção de espaço literário, de Maurice Blanchot:

A leitura do poema é o poema ele mesmo que se afirma obra na leitura que, no espaço mantido aberto pelo leitor, dá nascimento à leitura que o acolhe, torna-se poder de ler, torna-se a comunicação aberta entre o poder e a impossibilidade, entre o poder ligado ao momento da leitura e a impossibilidade ligada ao momento da escrita (Blanchot, 1955, p. 263, tradução nossa).

\section{Os corpos do texto e do livro}

Interessante notar ainda que, em Onde você está, estamos diante de um livro-objeto. Trata-se de uma tiragem pequena (160 exemplares) de uma produção artesanal: um caderno quadrado, fino, costurado à mão, com linha vermelha, que vem solto dentro de uma capa de papel-cartão preto, preso por um elástico. Abrimos o caderno, composto de folhas duplas, e encontramos apenas esses sete textos, escritos em blocos compactos cada um deles, divididos por folhas de papel cor creme de gramatura maior, sem paginação, nas quais se inserem os títulos de cada texto, escritos em vermelho, em fontes grandes. De modo que outro traço do que podemos chamar de performático estaria no próprio corpo do livro, em sua materialidade. ${ }^{6}$ Livro que, por si só, já solicita uma outra postura do leitor que o tem nas mãos. Não estamos diante de um livro convencional. A fisicalidade do livro já pede nossa atenção, apela aos sentidos.

Além da fisicalidade, também na disposição dos textos, na sua forma, seus modos de se encadear, logo notamos: não estamos tampouco diante de um livro convencional de poemas ou de contos. Não são narrativas exatamente, mas, ao mesmo tempo, há traços narrativos. Não são poemas, poderiam ser talvez poemas-em-prosa, há um tom que nos lembra a poesia, mas talvez também nos lembre o teatro, o gênero dramático. Ou seja, a questão do gênero literário aqui parece já não importar. Estamos em um terreno híbrido em que as relações entre diferentes elementos - e poderíamos dizer, diferentes modos de corporalidade (textura do papel, linha de costura, cores, manchas de texto, sons, falas de personagens, ritmos sonoros) se encontram e se misturam.

Podemos pensar, com Ana Cristina Cesar, que um texto performático é aquele que se joga aos pés, ou nos braços, do leitor. Como ocorre no poema de Walt Whitman, tão lembrado e apropriado por ela em seus poemas: "No final-despedida e chave de Leaves of Grass, ele [Walt Whitman] chega a dizer que aquele não é um livro: 'Sou eu que tu abraças e que te abraça', e mergulha com delícia nos braços de quem o lê - ou seja, de quem o toca" (Cesar, 1999, p. 252).

O livro mergulha nos braços do leitor. Walt Whitman, diz Ana Cristina, desejaria fazer "um Livro materialmente presente que diz ser o próprio poeta" (Cesar, 1999, p. 252). Todo poema seria movido por um desejo de ser materialmente presente, fisicamente palpável, corporalmente sensível para o leitor. Portanto, concordemos com Ana Cristina: "Todo o texto desejaria não ser texto" (Cesar, 1999, p. 266), desejaria ser carne, músculo, pele, hálito, respiração, tato. É essa

\footnotetext{
${ }^{6}$ Vale salientar que o livro foi editado na coleção Elixir, da qual um dos editores é outro poeta bastante afeito à questão da performance: o mineiro Ricardo Aleixo.
} 
presença, sempre marcada por um desejo alargado de corporalidade, que marcaria um traço performático da escrita: não o escritor, mas, sim, ela mesma que quer ser presente, ser presença, e explicita esse desejo em seus mais diferentes procedimentos.

Assim, o caráter performático da própria escrita pode expressar-se de muitas maneiras. E um outro caso contundente hoje é o trabalho de Sérgio Medeiros. ${ }^{7}$ De modo parecido com Manoel Ricardo de Lima, seus livros são pensados como um todo, enquanto projetos integrais ou seja, não são coletâneas de poemas ou textos em prosa soltos -, e têm como traço marcante sempre escaparem das determinações dos gêneros literários. Interessante notar que em Medeiros cada obra possui uma forma e um projeto distinto, sempre mesclando e subvertendo gêneros e formas literárias. Difícil seria encontrar um denominador comum ao conjunto de suas obras, composto das mais diversas experimentações criativas. Apenas como exemplos, pode-se citar: $O$ sexo vegetal $(2009$, p. 9), que oferece uma coleção de cenas poéticas, de "inspiração indígena", mas também "oriental", pelas quais passeia um mesmo personagem (Medeiros, 2009, p. 9); Figurantes, obra formada por uma sequência de poemas que descrevem personagens de uma estranha comunidade, em que cada título remete a um deles - "O primeiro a emergir", "O segundo", "O terceiro" etc. (Medeiros, 2010); O desencontro dos canibais, livro de contos que são, cada um, curiosamente separados em "capítulos", trazendo ainda um teor aparentemente infanto-juvenil - dos quais o personagem principal é um "canibalzinho" (Medeiros, 2013); As emas do general Stroessner e outras peças, coletânea de peças breves, com remissões à arte teatral, de teor político e extremamente irônico (Medeiros, 2017).

A experiência de se abrir um livro de Sérgio Medeiros é frequentemente desconcertante. Em geral, ficamos sem saber de fato de que modalidade de escrita se trata, se estamos diante de um conto, um ensaio, um poema, peça ou romance e, ainda, qual seu contexto, seu campo maior de inserção, de diálogos. Há um nonsense que se coloca desde a forma, mas também desde os títulos: $A$ idolatria poética ou A febre de imagens, por exemplo, não se refere a um livro de ensaios teóricos como pareceria, mas a um texto publicado na coleção de poesia da editora, escrito aparentemente em prosa dialogada, como se notas de "respectivas cadernetas de descritos" dos personagens "idólatras", que comporão uma narrativa - escrita, no entanto, de forma mais próxima à dramática. Em $O$ choro da aranha etc., os textos se aproximam mais da forma poema; além do título curioso, próximo de um tom infantil, traz subtítulos igualmente curiosos, que não parecem encaixar-se entre si, como: "A canção das minhocas" e "Waiting for the second time through / Memórias póstumas de Brás Cubas". Interessante o nonsense que atua desde a determinação do "lugar" dessa escrita e de como nos posicionarmos diante dela. Há sempre uma surpresa, um riso de estranhamento, uma sutil ironia ou gesto humorado. Sempre nos vemos no esforço de buscar um reconhecimento, dar lugar a uma escrita inquieta, que não se fixa.

Todas essas estratégias têm como efeito a intensificação da presença do corpo do texto, da página, do livro e da escrita. São estratégias que afirmam o caráter performático, nos termos aqui tratados, do projeto poético de Medeiros, sobretudo a partir do momento em que salientam o tempo real de nosso contato corporal com a obra. Sublinho como exemplar, acerca da presença desse forte traço de performance, o seu mais recente livro: Trio pagão (2018). Desde o sumário, Trio pagão nos deixa em suspensão, no esforço de compreender sua estrutura, que nos sugere serem três livros em um. Ao folhearmos, notamos que são, de fato, três partes bem diferentes entre si e que possuem, cada uma, o seu próprio sumário. A primeira delas, composta por desenhos/poemas visuais ("Esculturas de caligrafias"); a segunda, por uma narrativa fragmentada, misto de prosa e poesia ("Enrique Flor, o novo"); e a terceira, por uma escrita assemelhada a um diálogo (" $[\mathrm{O}]$ rio perdido").

Como veremos ao ler, a primeira parte é uma sequência do que poderíamos chamar de poemas visuais, que no livro ganham o nome de "esculturas de caligrafias", justamente por se formarem a partir do traço caligráfico. Essa parte não parece ter necessariamente relações

\footnotetext{
${ }^{7}$ Poeta nascido em Bela Vista (Mato Grosso do Sul) em 1959. É professor titular junto ao Departamento de Língua e Literatura Vernáculas da UFSC. Ganhou o Prêmio Literário Biblioteca Nacional 2017 na categoria Poesia, com a obra A idolatria poética ou A febre de imagens. Dentre seus livros, destacam-se também: O sexo vegetal (2009), Figurantes (2010) e Totens (2012). Também é tradutor, tendo traduzido o poema clássico ameríndio Popol Vuh.
} 
prévias com a que se segue, ou seja, a narrativa em que Medeiros prossegue com a sua personagem Enrique Flor, 8 um "músico português" bastante "inspirado" pela natureza. Veremos que a narrativa fragmentada é repleta de pequenos instantes cotidianos, de descrição atenta a detalhes dos locais e, sobretudo, aos sons, como em "o sino jovial da catedral badala longamente sem excesso de entusiasmo" (Medeiros, 2018, p. 94). A obra termina com um apêndice visual: 15 fac-símiles de 15 folhas arrancadas de um pequeno caderno, cada uma com uma pequena frase na base, referindo-se a elementos da natureza, como "Isto: uma bromélia tocou" ou "Isto: os pinheiros fitaram" (Medeiros, 2018, p. 136 e 137) (figura 1).
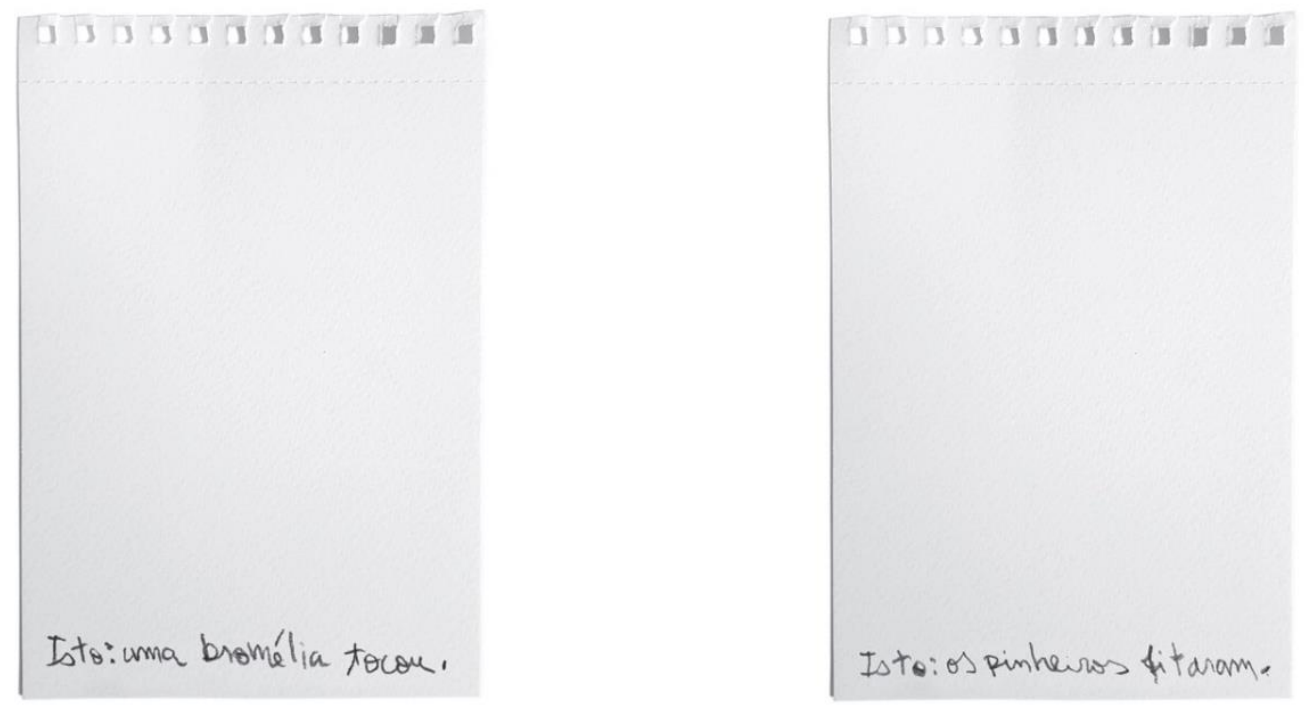

Figura 1 - Páginas de Trio pagão (Medeiros, 2018)

E então, na terceira parte, encontramos o subtítulo "[prosopopeia pagã]" para esse texto que, na nota inicial, o autor define como "um poema ou peça de teatro" - deixando claro aí, entre parênteses que: "(às vezes me é difícil distinguir uma coisa da outra)" (Medeiros, 2018, p. 159). As imagens de natureza, criadas a partir da sensorialidade corporal, lembram aquelas da narrativa precedente, de Enrique Flor. No entanto, aqui é como se houvesse um diálogo entre personagens, designados pela letra "[O]" (entre colchetes, como no título dessa parte), ora maiúscula, ora minúscula, e essas falas se espalham pela página, ora alinhadas no topo, ora na base.

É necessário observarmos que, em uma rápida folheada, já se nota o caráter experimental desse livro, na indecisão de gêneros, no seu hibridismo, nas variações inquietas das manchas de texto, da pontuação, das divisões de sequências. É o tempo todo uma escrita que se faz presente, enquanto materialidade, corpo, físico e movimento. Detenhamo-nos, neste sentido, um pouco na primeira parte, "Esculturas de caligrafias - vinte e três esculturas". Ela é precedida por uma nota introdutória e, em seguida, um poema, que age como uma apresentação do que virá depois:

\section{Um pescador}

Eu vivo vendo peixes-folha diante da minha casa, numa praia de Florianópolis. Esta foi uma das minhas últimas visões:

Diante do pescador sentado num banquinho na praia folhas marrons giram na areia com sol; então algumas escapam da roda e entram na água onde a linha do caniço mergulha.

Consegui pescar vinte e três peixes-folha, que são os poemas visuais que compõem este livro (Medeiros, 2018, p. 17).

\footnotetext{
${ }^{8}$ Personagem que já aparecia como protagonista de Totens (livro de 2012), inspirado no Henry Flower de Ulisses, de James Joyce.
} 
Essas "esculturas de caligrafias" - que o poema nomeia como "peixes-folha" e, em seguida, "poemas visuais" -, tiveram origem em um manuscrito realizado e dado a ele por um índio xavante, Jerônimo Tsawé, que se tornou seu amigo, conforme Sérgio Medeiros na nota introdutória. Esse manuscrito (figura 2), que já foi capa do livro Figurantes, agora retorna como inspiração para os 23 poemas-esculturas de Medeiros, que surgem como uma conversa desdobrada com o corpo da escrita, grafismos, de seu amigo. Notamos como os traços das supostas letras e frases, realizadas por Tsewé, vão se tornando, nos traços de Medeiros, um fluxo contínuo, que vai passando por metamorfoses (ver como exemplos as figuras 3 e 4). Essas grafias se tornam linhas, ziguezagueiam, acumulam-se e depois se separam, criam novelos na base e, dela, em seguida saltam, em jorros verticais. Multiplicam-se em mais linhas e depois se rarefazem, tornando-se uma só, que sobe sozinha para o alto. Para depois se acumularem, criarem blocos, saturarem-se, e voltarem a se diluir. E, nessas suas mudanças, de página a página, essas linhas caligráficas, em seus desenhos, ou "esculturas", produzem um ritmo: ritmo de passagem entre elas, como fotogramas. Como se essas esculturas, feitas de grafismo e de alusão ao fluxo da escrita, dançassem nas páginas, e entre as páginas, à medida que folheamos o livro.

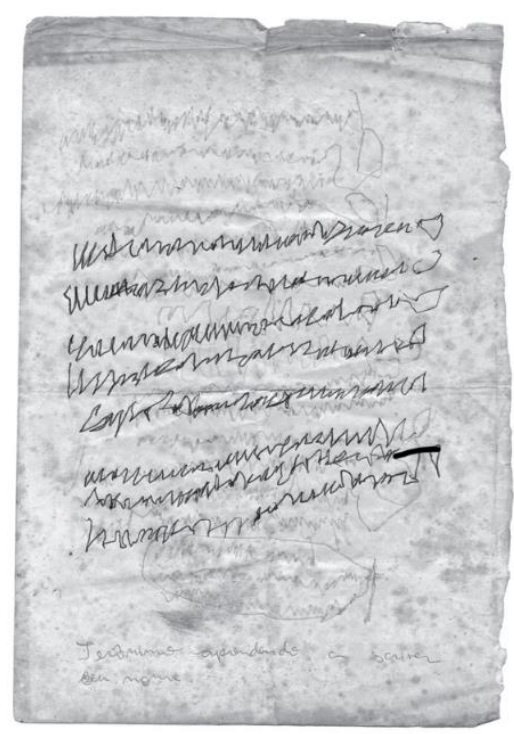

Figura 2 - Manuscrito do índio xavante Jerônimo Tsawé em Trio pagão (Medeiros, 2018)
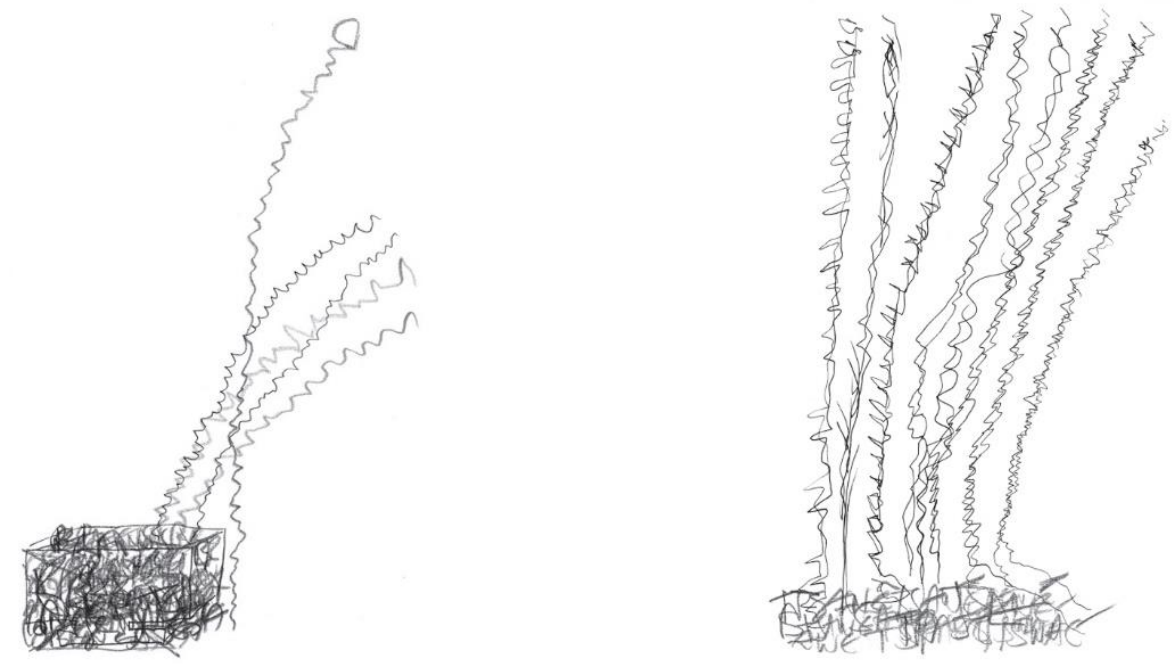

Figuras 3 e 4 - “Esculturas de caligrafias" em Trio pagão (Medeiros, 2018, p. 23 e p. 31) 
Há um corpo de palavras e de frases como que tornadas traços, movimentos, alternâncias de brancos, percursos na página. Um fluxo visual que nos lembra dos poemas-desenhos de Henri Michaux, nas obras Par des traits e Par la voie de rythmes, em que temos poemas visuais em um sentido muito especial, de uma grafia que se torna ritmo e quase uma partitura para os olhos; a busca de Michaux por construir uma língua mais íntima, livre das convenções e restrições dos idiomas. ${ }^{9}$ Vê-se que, em ambos os casos, podemos dizer que há uma escrita, uma caligrafia, ainda que não seja uma escrita da ordem da significação, na qual funciona a nossa linguagem verbal. Mas há um corpo do escrito que é fluxo, e que é composto pela ligação criada entre as palavras e entre as frases, em seus intervalos. E esse fluxo toma nosso corpo, buscando nos engajar em seu percurso, fazendo-nos seguir seu movimento, suas circunvoluções e ziguezagues, seus momentos de rarefação e condensação, seus encolhimentos e distensões (figura 5, notar as variações entre as figuras). Tal movimento poderia ser comparado àquele que sentimos na dinâmica das vozes em Manoel Ricardo de Lima: a voz tornada fluxo, seu fluxo tornado corpo material, que se corporifica em nossa leitura. Quase como se pudéssemos sentir ecoar nas esculturas caligráficas de Medeiros os movimentos e circunvoluções das vozes em Lima.

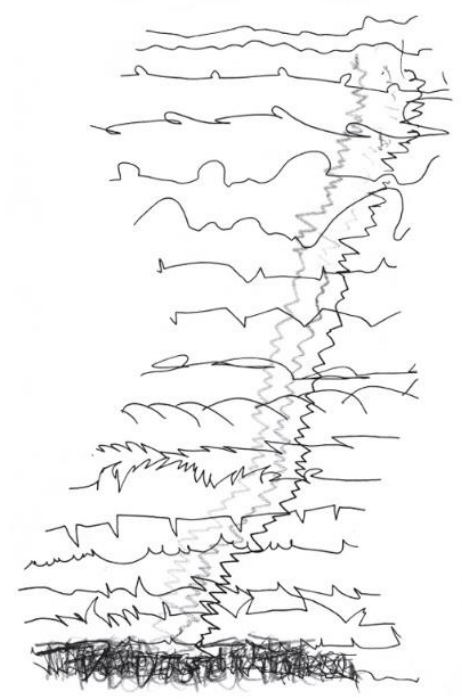

Figura 5 - Outra "Escultura de caligrafia”, em Trio pagão (Medeiros, 2018, p. 57)

\section{O corpo do instante}

Uma escrita performática passa por uma presença evidenciada do corpo no próprio escrito. Independentemente de se este escrito vai ou não ser publicamente performado depois. Mas não se trata aqui da presença do corpo daquele que escreve: não o corpo do poeta (biológico, fisiológico, orgânico) enquanto a origem, para sempre perdida, do texto. Mas, sim, a presença do corpo do próprio físico da palavra, que é som, traço, textura, visualidade e audibilidade. Corpo que se torna ritmos, movimentos, respiração ao ser animado pelo corpo daquele que lê; o texto faz corpo no corpo do leitor, no qual ele irá se encarnar, e se tornar vibração, e atualizar o seu fluxo. A performance se dá, assim, no momento em que o texto, posto em movimento pelo leitor - mesmo em uma leitura silenciosa -, atualiza seu potencial performático, que é precisamente esse potencial de fazer proliferar fluxos corporais no aqui-agora do tempo da leitura.

A escrita performática se definiria por uma corporalidade e uma presença, em primeiro lugar. Em segundo, ela implica uma ação: a linguagem aqui não opera mais apenas no regime

\footnotetext{
${ }^{9}$ Gonzalo Aguilar, que assina um breve texto introdutório a essa parte, menciona a proximidade com outro livro de Michaux, Misérable miracle (1972), em que se tem sua experiência com a mescalina (e os desenhos desta decorrentes) entretanto, a proximidade maior parece-me estar com esses outros, em que encontramos de fato aquilo que Michaux (1984) definiu por uma escrita em estado nascente - ou seja, em um idioma ainda desconhecido, em estado de surgimento.
} 
de representação, do isto quer dizer aquilo. Como nos poemas visuais ou esculturais caligráficas de Sérgio Medeiros: não se trata de dizer algo, de passar uma mensagem ou significado. A grafia pode nada significar. Antes de tudo, ela possui um movimento, um corpo que se move e nos engaja em seu fluxo. Como vimos em Manoel Ricardo de Lima, a voz salta e se faz fluxo vocal. E as imagens e anedotas são apenas secundárias em relação ao engajamento corporal dessas vozes. A língua é aqui ação, é um fazer, um atuar no mundo, e não um "falar sobre" o mundo e as coisas. E haveria algo político implícito aqui, em uma afirmação da língua enquanto corpo e possibilidade de intervenção no mundo:

Quando a poesia está vinculada a uma aventura para nada e que tem a ver com o corpo numa temporalidade política para intervir no mundo não apenas como uma tarefa estratégica de escrita, mas como algo que pode provocar um desvio. Um palmo para o lado, que seja. E aí, se a vinculo a uma imagem expandida de uma ação política, como experiência e resistência, não posso entender a poesia apenas como literatura mas como um fazer (Lima, 2014).

Em relação a esse fazer, e à literatura como ação, podemos pensar que, afinal, agir é estar presente - como no teatro: "a ação só existe no presente, quando sob nossos olhos vemos uma situação modificar-se pelas determinações dos personagens" (Touchard, 1978, p. 169). A ação teatral é presente e se modifica, conforme já sublinhava Touchard em 1952, "sob nossos olhos". Mesmo que nos casos de que nos ocupamos aqui não se tenha personagens no sentido tradicional do termo, $\mathrm{o}$ que destaco daí é a ideia de testemunho de uma ação que se dá em tempo presente: a ideia de se presenciar em tempo real as modificações, as emergências de atos, falas, que se desenrolam no instante único do acontecimento da apresentação.

O que definiria, assim, uma performance da própria escrita seria esse ato em que ela dá a ver o tempo do instante, da irrupção das coisas, que é o tempo da ação, do devir, do "ao vivo". ${ }^{10}$ Trata-se de um ato em que se torna sensível o imprevisto de sua própria aparição, enquanto corpo caligráfico, escrito, voz. Estou aqui-agora, ao vivo - nos diz o corpo do texto -, estamos neste espaço partilhado que se cria neste instante, pela primeira e única vez. Intermezzo, partilha deste espaço-tempo que irrompe no instante da leitura. Embate de presenças, mistura de corpos. Como em cada encontro, em que sempre algo de inédito se dá, mesmo que nas frestas, mesmo que naquilo que é o inapreensível - das singularidades, dos pequenos gestos, daquilo que passa como se fosse secundário. Jamais um corpo repete o mesmo gesto no mesmo espaço-tempo; se repetimos é porque ele já não é o mesmo, ele já inseriu uma diferença. Algo próximo do que queria Antonin Artaud com seu teatro da crueldade: "Temos necessidade de que o espetáculo ao qual assistimos seja único, que ele nos dê a impressão de ser tão imprevisto e tão incapaz de se repetir quanto qualquer ato da vida, qualquer acontecimento trazido pelas circunstâncias" (Artaud, 1995, p. 34).

A crueldade é, em Artaud, o retorno do corpo ao palco e ao texto. Estamos no acontecimento, e ele se dá ao vivo - e é irrepetível, como qualquer ato ou fato da vida. Mas isso pode ser assustador. Daí tantas estratégias da nossa cultura para fugir ao instante presente. Fugir do corpo, de suas ameaças; fugir do tempo do devir, do imprevisto. A voz é presença; mas é como se sempre, um pouco deslocados, nos retirássemos dela. Retiramo-nos da voz através da significação, das abstrações - retiramo-nos pelas antecipações, previsões -, ausentamo-nos da nossa própria voz indo ao passado ou ao futuro: a todo tempo saímos do presente. Do presente da leitura, por exemplo. Retiramo-nos da presença do texto, de seu fluxo, nos modos retóricos, nas convenções da língua, da comunicação, nas classificações de gênero, nas interpretações de significados e conteúdos. Com isso, saímos do corpo, da presença e do presente do corpo, por convenções e por hábitos da cultura. E para nós o mais imediato, o mais evidente - a presença, o corpo, a voz - é o mais difícil. Simplesmente estar no acontecimento. No tal aqui-agora, na presença plena do que se dá, no tempo-espaço do corpo, no corpo que se

\footnotetext{
${ }^{10}$ Acerca da temporalidade "ao vivo" da performance da escrita, em outros autores contemporâneos, ver: "Ao vivo, performance da voz em Tarkos e Aperghis" (Malufe e Ferraz, 2017).
} 
move aqui-agora, irremediavelmente no presente. "A performance não pode ser outra coisa senão presente", dizia Zumthor (2005, p. 93).

Assim, algo ético e político se esboça no gesto performático da arte. Nessas propostas ocorre um resgate do corpo enquanto sensação e vivência do fluxo do devir. E, nisso, talvez, encontremos nelas um papel político e ético. Uma tarefa deixada por Nietzsche ao pensamento ocidental: não podemos fugir ao corpo, somos antes de tudo carne, fome, desejo e necessidade de abrigo.

\section{Referências}

ARTAUD, Antonin (1995). Linguagem e vida. Tradução de J. Guinsburg et al. São Paulo: Perspectiva.

BECKETT, Samuel (1953). L'innommable. Paris: Minuit.

BERNSTEIN, Ana (2004). Atos da fala, representação teatral e teorias da performance. Folhetim, n. 20, jul./dez.

BLANCHOT, Maurice (1955). L'espace littéraire. Paris: Gallimard; Folio, 1955.

CESAR, Ana Cristina (1999). Crítica e tradução. São Paulo: Ática.

DELEUZE, Gilles (1992). L'épuisé. In: Beckett, Samuel. Quad: et autres pièces pour la télévision. Paris: Minuit.

LEHMANN, Hans-Thies (2007). Teatro pós-dramático. Tradução de Pedro Süssekind. São Paulo: Cosac Naify.

LIMA, Manoel Ricardo (2014). La poesía como un hacer. [Entrevista cedida a] Aníbal Cristobo. Vallejo and Co., Peru, 5 feb. Disponível em: https:/ / bit.ly/2MQeYrT Acesso em: 20 set. 2018.

LIMA, Manoel Ricardo (2016). Onde você está. Belo Horizonte: Elixir.

MALUFE, Annita Costa; FERRAZ, Silvio (2017). Ao vivo, performance da voz em Tarkos e Aperghis. E-Lyra, Porto, v. 10, p. 91-112, dez. Disponível em: http://www.elyra.org/index.php/elyra/article/view/206/252 Acesso em: 20 set. 2018.

MEDEIROS, Sérgio (2009). O sexo vegetal. São Paulo: Iluminuras.

MEDEIROS, Sérgio (2010). Figurantes. São Paulo: Iluminuras.

MEDEIROS, Sérgio (2018). Trio pagão. São Paulo: Iluminuras.

MICHAUX, Henri (1972). Misérable miracle. Paris: Galimmard; Folio.

MICHAUX, Henri (1974). Par la voie des rythmes. Paris: Fata Morgana.

MICHAUX, Henri (1984). Par des traits. Paris: Fata Morgana.

MOSTAÇO, Edélcio et al. (org.) (2009). Sobre performatividade. Florianópolis: Letras Contemporâneas.

TOUCHARD, Pierre-Aimé (1978). Dionísio e O amador de teatro. São Paulo: Cultrix.

ZUMTHOR, Paul (1997). Introdução à poesia oral. Tradução de Jerusa Pires Ferreira et al. São Paulo: Hucitec.

ZUMTHOR, Paul (2000). Performance, recepção, leitura. Tradução de Jerusa Pires Ferreira e Suely Fenerich. São Paulo: Educ.

ZUMTHOR, Paul (2005). Escritura e nomadismo. Tradução de Jerusa Pires Ferreira e Sonia Queiroz. Cotia: Ateliê. 